\title{
Improving EFL Students' Higher Order Thinking Skills Using Reading Strategies
}

\author{
Arik Susanti ${ }^{1, *}$ Sarah Lailiyah ${ }^{1}$ \\ ${ }^{1}$ English Education Department, Universitas Negeri Surabaya, Surabaya, Indonesia \\ *Corresponding author.Email: ariksusanti@unesa.ac.id
}

\begin{abstract}
In the $21^{\text {st }}$ century, learners must master higher-order thinking skills (HOTS) to solve problems in their life easily. This study aims to investigate whether reading strategies can increase students' higher-order thinking skills for students. It was an experimental study that was held in MAN 1 Mojokerto, East Java Indonesia. The participants were students in eleventh graders that were divided into the experimental and control group. Both of the groups were given pre-test and post-test to know the different results of their achievement after the experimental group was conducted treatment. The data was analyzed using SPPS. The result showed that there was a significantly different mean score of post-tests between the experimental group and the control group. The mean score of the experimental group was higher than the control group which shows a .000 level. To sum up, reading strategies can improve students' higher-order thinking skills. It is recommended EFL teachers should apply many kinds of strategies in the learning process to motivate and engage in studying English.
\end{abstract}

Keywords: Reading strategies, higher-order thinking skills, improve, English

\section{INTRODUCTION}

Currently, the learner must master soft skills to get a job easily and solve problems. One of the skills that seem to be crucial in the EFL classroom is higher-order thinking skills or HOTS. It is stated if the students have higher-order thinking skills, it can motivate their critical thinking skills [1]. Students use HOTS to acquire new information, hold it in memory, combine it, connect it to existing knowledge, and generate it in order to achieve a goal or solve a challenging problem. HOTS is the highest level in the cognitive process hierarchy, and it involves the use of the mind to deal with new challenges [2], since it may need the individual to interpret, analyze, or manipulate information [3]. When students demonstrate higher-order thinking skills, they are able to address issues or occurrences that necessitate a unique response [4]. Students use critical thinking, logical, introspective, metacognitive, and creative abilities in this scenario. It could encourage students to engage in the process of learning reading.

To have higher-order thinking skills, students must improve their reading comprehension to have the capacity for learning, speed, and adequate learning procedure [5]. It means that higher-order thinking skills are assertive and learnable. Five types of higher-order thinking skills are problem-solving, critical thinking, creative thinking, reasoning, and decision making [5]. Furthermore, students must learn some aspects of language such as vocabulary and grammar to master HOTS.

Thinking abilities are a vital part in the educational process for developing students' HOTS since they are involved with the learning process and there is a direct association between thinking and learning skills [6]. Students are taught to think in order to have a beneficial influence on the advancement of their education. The two basic stages in gaining thinking abilities are perception and processing [7].

Learning styles are described as a person's aptitude and inclination to perceive and process information[8]. Thinking skills are a major thing in the educational process. An individual idea can influence the capacity of learning, speed, and viability of learning. Therefore, thinking skills are related to the learning process because there was a close connection between deduction aptitudes and learning [9]. Students are prepared to think to exhibit a positive effect on the advancement of their instruction. Recognition and handling are the two fundamental procedures in getting the hang of reasoning abilities [1]. The capacity and inclination of an individual in seeing and handling information are different. 
This propensity of the learning condition is characterized as learning styles.

However, the data reveal that kids' higher-order thinking skills remain inadequate. Students' restricted vocabulary is one of the signs that their higher-order thinking skills are lacking. Most of them get difficult to guess the meaning of the words in the context. They are not able to understand deeply in their reading context or they do not know the implied meaning of the certain text. They only memorize what they have read in certain text and understand the surface meaning of the text. They do not have any freedom or independence to analyze a certain text. Most of them rely on the teacher's instruction. Finally, they feel difficult to generate creative ideas.

To solve the problem, reading strategies could be implemented to promote students' higher-order thinking skills[10]. It has been mentioned that the reading strategy is an effective cognizance because it can help students to highlight important information in reading text. It is useful for students since this technique makes their reading fruitful [2]. It is said that reading techniques are characterized as plans and practices for taking care of issues when students face in developing significant texts. They can think within and beyond the text [11]. Thus, reading strategies would be helpful for students to improve their higher-order thinking skills.

Several studies have discussed the use of reading strategies. It was shown that reading techniques had a solid positive relationship with reading perception accomplishment between male and female students. Furthermore, it is said that higher-order thinking skills could enable students to think creatively and critically [12]. Students' collaboration also improves since they work in a group to solve a certain problem. The students have high motivation to learn English, especially reading text.

To fill the gap, this study would focus on mind mapping and visualization strategies to improve students' HOTS. Mind mapping and visualization is an effective graphic technique that provides a universal key to increasing brain potential since mind maps have many types of cortical skills - words, images, numbers, logic, rhythm, color, and spatial attention - in one unique and powerful way[13]. Moreover, mind maps give freedom to patterns or ideas that will be written down what is in their brain that can improve students' critical thinking to arrange new ideas [14]. It is also in line with the visualization strategy that is utilized to accomplish extensive understanding and worldwide intelligibility of the content. Visualization is the ability to build mental pictures or images while reading [15] that makes a text come alive for readers. Visualization or imagery is provenly effective in defining concrete words because it is imageable and useful in daily activities so that the readers are easier to memorize and understand the meaning of the words. Therefore, the research question of this paper was based on the background above the whether the reading strategy can improve students' higher-order thinking for EFL senior high school.

\section{METHOD}

It was experimental research that consisted of two groups namely experimental and control groups. In the experimental group, the participants would be given treatment such as the process of teaching-learning reading using reading strategies, mind mapping, and visualization, to improve students' HOTS. The samples of this study were 60 students in eleventh grade who were studying English, especially reading comprehension in one of the Islamic senior high schools in Mojokerto, one of the suburb areas in East Java, Indonesia. The total samples would be divided into two groups 30 participants in the control group and 30 participants in the experimental group.

The instruments of the study were tests, divided into two, pre-test and post-test. They were essay tests consisting of 15 numbers and one writing test to know students' HOTS. A pre-test was given for both groups before the treatment was conducted. The function of the pre-test was to find out the initial condition before treatment. After the pre-test was done, the experimental group would get the treatment that was learning reading using mind mapping and visualization strategies to improve students' HOTS. This treatment lasted for almost 2 months or 8 sessions that lasted for 90 minutes. since the topic of the reading was hortatory exposition, that was quite difficult for students. Both groups were given a post-test to know whether there was an improvement in students' HOTS. After they answered the questions based on the topics that had been given, students submitted. Next, it would be assessed based on the rubric provided namely, the essay rubric and writing rubric. For the writing rubric consisted of content, organization, vocabulary, language use, and mechanics.

There were some procedures how to collect the data. First, after it had given permission, both groups were taken pre-test to know the students' competence (HOTS). Next, the experimental group learned reading using mind mapping and visualization to improve their HOTS. It was done for 8 sessions but the control group studied reading using the traditional method. After the treatment was ended, both were given a post-test to know whether there was an improvement in students' HOTS or not.

The data will be examined using SPSS to compare the students' pre-test and post-test results from both the experimental and control groups. It was also used an independent sample T-test to know the t-value. The t-value was calculated to see whether there was a statistically significant difference between the control and experimental groups. If the score is less than 0.05 , it is possible to conclude that there was a statistically significant difference between the experimental and control groups. Following that, it could be determined whether or not the usage of reading methods improved students' HOTS.

\section{RESULT AND DISCUSSION}

\subsection{RESULTS}

The result of the pre-test showed that the mean score of the control group was 58,300 (SD = 5,9663) and the 
experimental class was 56,367 (SD = 9,7573). It was indicated that the mean score of the control group was higher than an experimental class. To make sure the result, would be calculated using independent samples t-test.

Table 1. The Result of Pre-Test

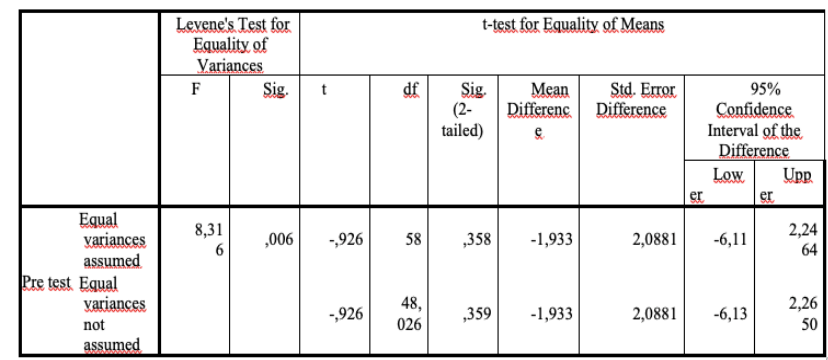

Table 1 showed that the results of significant 2tailed were .358 level along with the $95 \%$ Confidence Interval. It means that the sig. (2-tallied) was greater than 0.05 so that it could be interpreted that both groups do not have any significant difference or they were in an equal position.

The outcome of the post-test between the two groups would then be computed. It was known that the experimental group's mean post-test score was $88,067(\mathrm{SD}=5,7711)$, whereas the control group's mean post-test score was 65,033 (SD = 4,7160). It was discovered that the experimental class's mean score was greater than the control class's. Then, to determine whether or not there was an improvement, an independent sample t-test would be used. The results of the independent sample t-test were explained in Table 2.

Table 2. The Result of Post-Test

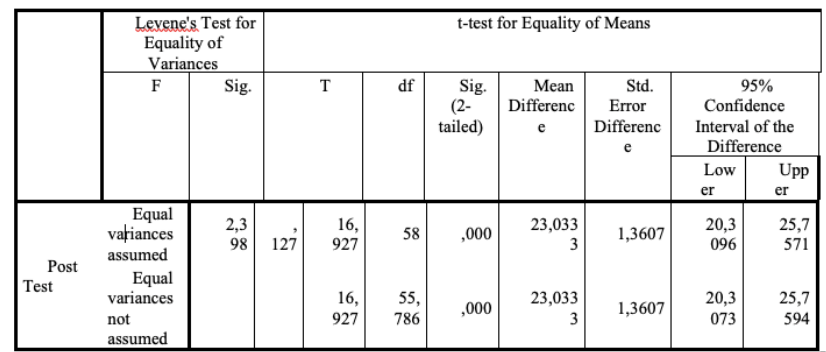

According to the table, the significance (2-tailed) value was.000 or less than.05. According to Pallant (2013), a significant difference between the two groups was indicated if the significance (2-tailed) value was.05 or less than.05. Based on the findings, it is possible to conclude that the posttest mean score of the control and experimental classes was substantially different, implying that the alternative hypothesis is correct.

\subsection{DISCUSSION}

The result exposed that the average scores for the experimental group were higher than the control group. Moreover, the result of the significance (2-tailed) score was .000 , which is lower than .005 . Using $95 \%$ of the confidence interval that is 0.05 , it could be said that the alternative hypothesis could be accepted. It was assumed that using reading strategies could improve students' higher-order thinking skills.

In the process of teaching-learning, strategy has an important role to help students to understand the material of reading. If the teacher implements specific methods or designs, it could help students to imagine something and finally help them to understand a certain text. Moreover, it could also manipulate and control students' behavior to interpret something. Metacognitive strategies also help students to shape their higher-order thinking. In this opportunity, many strategies are applied by students to improve their higher-order thinking skills. They use notetaking, graphic organizers, skimming, mind mapping, and visualization. The use of mind mapping and visualization create students to be more enthusiastic when they learned reading. The use of pictures, graphics, or charts helps students to guess the topic of the text or the title of the text. The use of visualization also helps students to understand the main idea of the text or to generate ideas easily and quickly. It can be said that graphic organizers and visualization become the medium for ideas representation in both narrative and expository texts [16]. It is said that reading strategies were an effective way to improve students' higher-order thinking skills [17]. It was known that reading strategies are the mental operations involving readers to make sense of what they have read.

\section{CONCLUSION}

According to the study's findings, reading approaches have an important role in enhancing pupils' higher-order thinking skills. The use of graphic organizers, mind mapping, and visualization can help people find the main topic or subject of a book. They may also help students come up with ideas and predict the meaning of certain phrases. It is suggested that other researchers continue this research by applying other reading tactics that assist pupils in understanding reading comprehension.

\section{ACKNOWLEDGMENT}

We would say thank you to Ibu Pratiwi, as the head of the English Department, and all of the people that help us to finish this study.

\section{REFERENCES}

[1] K. N. Shafeei, H. Hassan, F. Ismail, and A. Abdul Aziz, "Incorporating Higher Order Thinking Skill (HOTS) Questions in ESL Classroom Contexts," LSP Int. J., vol. 4, no. 1, pp. 101-116, 2018, doi: 10.11113/1spi.v4n1.49.

[2] B. S. Indriyana and P. Kuswandono, "Developing Students Higher Order Thinking Skills (HOTS) in Reading: English Teachers Strategies in Selected Junior High Schools," JET (Journal English Teaching), vol. 5, 
no. 3, p. 204, 2019, DOI: 10.33541/jet.v5i3.1313.

[3] Z. Ali, "A Case Study on Collaborative Learning to Promote Higher Thinking Skills (HOTS) among English as a Second Language (ESL) Learners," J. UMP Soc. Sci. Technol. Manag., vol. 1, no. 1, pp. 1-14, 2009, [Online]. Available: http://umpir.ump.edu.my/5069/.

[4] G. Thomas and A. Thorne, "How To Increase Higher Level Thinking," Metairie, LA Cent. Dev. Learn., no. 2009, pp. 1-17, 2009, DOI: http://www.cdl.org/resource-library/articles /HOT.php?type=subject $\&$ id $=18$.

[5] S. Shirkhani and M. Fahim, "Enhancing critical thinking in foreign language learners," Procedia - Soc. Behav. Sci., vol. 29, pp. 111-115, 2011, DOI: 10.1016/j.sbspro.2011.11.214.

[6] A. H. Abdullah, N. L. Z. Abidin, and M. Ali, “Analysis of students' errors in solving Higher Order Thinking Skills (HOTS) problems for the topic of fraction," Asian Soc. Sci., vol. 11, no. 21, 2015, DOI: 10.5539/ass.v11n21p133.

[7] A. H. Kusumah, “A Study of Teachers' Perception on English Curriculum for Vocational High School in Surabaya," Univ. Negeri Surabaya, vol. 6, no. 1, pp. 104-111, 2018.

[8] C. Jerome, J. A. C. Lee, and S. H. Tang, "What students need: Instructional strategies that enhance higher-order thinking skills (HOTS) among Animas undergraduates," Int. J. Bus. Soc., vol. 18, no. S4, 2017.

[9] J. H. Reed, "Effect of a model for critical thinking on student achievement in primary source document analysis and interpretation, argumentative reasoning, critical thinking dispositions, and history content in a community college history course," ProQuest Diss. Theses, p. 263, 1998, [Online]. Available: https://search.proquest.com/docview/304454601?accou ntid=10673\%0Ahttp://openurl.ac.uk/redirect/athens:ed u/?url_ver=Z39.88-

2004\&rft_val_fmt=info:ofi/fmt:kev:mtx:dissertation\&g enre=dissertations $+\&+$ theses $\&$ sid=ProQ:ProQuest+Dis sertations $+\&+$ Theses+Global\&atit.

[10] P. Afflerbach, P. D. Pearson, and S. G. Paris, "Clarifying Differences Between Reading Skills and Reading Strategies," Read. Teach., vol. 61, no. 5, pp. 364-373, 2008, DOI: 10.1598/rt.61.5.1.

[11] A. Asmawati, “in Improving Students ' Reading Comprehension At," Eternal, vol. I, no. 01, pp. 69-83, 2015.

[12] A. Munawati, "The Effectiveness of HOTS (Higher Order Thinking Skill) in Teaching Reading Comprehension," Educ. English as a Foreign Lang., vol. 2, no. 1, pp. 32-43, 2019, DOI: 10.21776/ub.educated.2019.002.1.5.

[13] A. A. Wilson and K. J. Chavez, Reading and representing across the content areas. 2014.

[14] L. T. Luck, F. Hashim, and S. Z. M. Din, "A Creative and Literary Writing Digital LMS in Supporting Writers' Group Learning and Knowledge Sharing among Creative Writers," Procedia - Soc. Behav. Sci., vol. 67, pp. 238-249, 2012, DOI: 10.1016/j.sbspro.2012.11.326.

[15] E. Papatga and A. Ersoy, "Improving reading comprehension skills through the SCRATCH program," Int. Electron. J. Elem. Educ., vol. 9, no. 1, 2016.

[16] M. Ganapathy, "Promoting Higher Order Thinking Skills via Teaching Practices Promoting Higher Order Thinking Skills via Teaching Practices Many educators acknowledge the importance of critical thinking in the educational curricula development of critical thinking skills," Southeast Asian J. English Lang. Stud., vol. 23, no. 1 , pp. 75-85, 2017.

[17] S. Ramdiah, Abidinsyah, M. Royani, and Husamah, "Understanding, planning, and implementation of HOTS by senior high school biology teachers in Banjarmasin-Indonesia," Int. J. Instr., vol. 12, no. 1, 2019, doi: 10.29333/iji.2019.12128a. 